\title{
Sheep gut passage and survival of Mediterranean shrub seeds
}

\author{
Pablo Manzano*, Juan E. Malo and Begoña Peco \\ Departamento Interuniversitario de Ecología, Facultad de Ciencias, Universidad Autónoma de Madrid, \\ E-28049 Madrid, Spain
}

\begin{abstract}
Although viable seeds of Mediterranean dry-fruited shrubs are found in herbivore dung, the ecological importance of this observation is still not well understood. We analysed seed retrieval percentages, defecation time and germinability after sheep gut passage for the five most common shrub species of an area in central Spain (Retama sphaerocarpa, Cytisus scoparius, Halimium umbellatum subsp. viscosum, Cistus ladanifer and Lavandula stoechas subsp. pedunculata). Five ewes were fed seeds, and their dung was collected regularly during the following week. Seeds were hand-sorted from dung subsamples and tested for germinability. The defecated seeds were clustered in time, with a majority retrieved. in the $24-40 \mathrm{~h}$ period, although over $1 \%$ of the sededs were retained in the gut for more than $72 \mathrm{~h}$. Data suggested a possible link between seed size and retrieval, with medium-sized seeds less damaged $(16-23 \%)$ than larger and smaller seeds $(10-12 \%)$, although only a small number of species were studied. Germination results showed an increased percentage of germination after gut passage for $H$. umbellatum $\left(\chi^{2}\right.$ test, $P<0.05)$ and a marginally significant difference for $C$. scoparius $(P<0.1)$. Soft-seeded $L$. stoechas did not germinate after gut passage. The results indicate a potential role of herbivore endozoochory for the long-distance dispersal of dry-fruited shrubs and their potential colonization of distant sites.
\end{abstract}

Keywords: colonization, dung, dry-fruit, endozoochory, germination, herbivore, dispersal, scrub, sheep
${ }^{*}$ Correspondence

Fax: + 34914978001

E-mail: pablo.manzano@uam.es

\section{Introduction}

Seed dispersal by animals has attracted scientific attention for a long time, although research has mainly focused on the fate of fleshy fruits (Traveset and Verdú, 2002). The role of herbivores as endozoochorous dispersers of dry-fruited species has received less attention, but the Janzen (1984) proposal of the 'foliage as fruit' hypothesis has boosted research in the area. In short, this hypothesis states that foliage can act as an attraction and reward for herbivores, as much as fruit flesh for frugivores. Thus, plants could benefit from dispersal and pay back dispersers with photosynthetic tissue and a fraction of seeds that are digested by herbivores.

Dry-fruited shrub species with small seeds of many families in the Mediterranean (e.g. Leguminosae, Cistaceae, Labiatae, Ericaceae) lack obvious means of long-distance dispersal, and endozoochory could play an important role for them (Malo and Suárez, 1996). Dispersal of some seeds away from the mother plant is a key element in the life cycle of pioneer dry-fruited shrubs, as they persist in landscapes through a combination of scrub resilience (survival after perturbations, often linked to wildfire) and the establishment of new populations at points where disturbances generate gaps (Keeley, 1991; DeSimone and Zedler, 2001). Available data suggest that abiotic dispersal does not explain the distances reached by new colonizers of open places, either by wind or by ballistic dispersal (Cain et al., 1998; Sánchez and Peco, 2002; Malo, 2004). Less obvious mechanisms of longdistance dispersal should, therefore, be responsible for the arrival of pioneer shrubs at locations where new populations are established. In fact, there is a general lack of data on 'long-distance seed dispersal', understood as the extreme $1 \%$ tail of the seed shadow, and the relevance of knowledge about long-distance dispersal events has become evident when modelling vegetation changes linked to climate change (Cain et al., 2000). Although endozoochory may generate large seed losses, this dispersal mechanism is capable 
of spanning the distances needed to account for rapid plant migration (Pakeman, 2001). In order to model seed shadows generated by animals, the transit time of seeds through the gut has to be investigated, and particular attention has to be paid to the seed fraction retained in the gut for longer periods.

The importance of herbivore endozoochory has been highlighted (Campbell and Gibson, 2001; Pakeman, 2001), and several studies have shown the presence of dry-fruited shrub seeds in herbivore dung (e.g. Malo and Suárez, 1996; Sánchez and Peco, 2002). However, very little is known about the fate of their seeds after passage through guts (Traveset and Verdú, 2002). The quantification of seed lopses caused by chewing and digestion is essential in order to assess the potential benefits of this strategy. Seed mastication depends on size and hardness, and the potential role of digestive processes in breaking seed dormancy is still partially unknown. Pakeman et al. (2002) found that small, round weed seeds best survived gut passage. Again, many studies link dormancy breaking in various hard-coated seeds to fire exposure or scarification (e.g. Thanos et al., 1992; Delgado et al., 2001; Pérez-Fernández and RodríguezEcheverría, 2003). However, increases in germinability have also been observed following herbivore digestion, and the utility of hard seed coats in plant reproduction can be multiple (Russi et al., 1992; Malo and Suárez, 1996). Resistance of seeds to bovine digestion can depend on the proportion of hard (physical dormant) and soft (non-dormant) seeds, given that non-dormant seeds may initiate imbibition in the gut and be digested (Gardener et al., 1993). Thus, hard-seededness may be an important feature for plant species to take advantage of herbivore dispersal.

The aims of this study were: (1) to ascertain the temporal pattern of seed defecation by sheep, with special regard to the size of the final 'tail', and (2) to quantify the percentage of seed survival of the most common dry-fruited shrub species in the study area. Seeds ranged largely in size among the studied species, and there were representatives of both hard-coated (Cistaceae and Fabaceae) and soft-coated (Labiatae) families.

\section{Materials and methods}

Five characteristic shrub species of central Spain were chosen to represent a gradient in seed size (Table 1). Seeds were fed to five ewes from a herd of the Rubia del Molar breed held at the Veterinary Faculty (Universidad Complutense de Madrid). The animals were fed with plant fodder and barley grain, and had free access to water and straw during the experiment. The herd did not graze in the open, since it is kept for teaching purposes in the faculty stables.

Seeds used in the experiment were of commercial origin from a forestry nursery in Madrid Province, with the exception of Halimium umbellatum, which were collected from a wild population in Pedrezuela (Madrid). The seeds (3750 of Retama sphaerocarpa, 25,000 of Cistus ladanifer and 10,000 of each of the other species) were mixed with barley grains, and offered as one large sample to the set of animals, which ate the mixture completely. The restless nature of the breed and the low-intensity management of the flock precluded the possibility of working with animals as independent replicates of the experiment. The faeces were then collected in specially designed bags attached to the back of the animals (Fig. 1), keeping those of each animal separate. Faeces collection was carried out every $8 \mathrm{~h}$ during the first $64 \mathrm{~h}$, and thereafter every $12 \mathrm{~h}$ until $172 \mathrm{~h}$. The samples were air-dried immediately after collection to avoid seed fermentation and damage.

Air-dry dung was weighed, and a $20 \mathrm{~g}$ subsample was removed from each dung sample for the seed content analysis. The $20 \mathrm{~g}$ subsamples were crumbled and sieved through a $500 \mu \mathrm{m}$ net prior to seed sorting under a $10 \times$ magnifying glass. Only seeds with no apparent external damage were sorted and considered to be potentially viable (referred to 'retrieved seeds', hereafter). Following this process, the remainder was mixed with sterile soil, spread in $1 \mathrm{~cm}$ layers over $6 \mathrm{~cm}$

Table 1. Species used in the study and main characteristics of their seeds

\begin{tabular}{|c|c|c|c|c|c|}
\hline \multirow[b]{2}{*}{ Species } & \multicolumn{3}{|c|}{ Seed size $(\mathrm{mm})$} & \multirow[b]{2}{*}{ Mass (mg) } & \multirow[b]{2}{*}{ Source } \\
\hline & Length & Width & Height & & \\
\hline Retama sphaerocarpa & 6.5 & 4.9 & 3.8 & 77 & The present study \\
\hline Cytisus scoparius & 3.3 & 2.4 & 1.2 & 8.7 & Azcárate (2003) \\
\hline $\begin{array}{l}\text { Halimium umbellatum } \\
\text { subsp. viscosum }\end{array}$ & 1.6 & 1.3 & 1.3 & 1.4 & Azcárate (2003) \\
\hline Cistus ladanifer & 0.97 & 0.55 & 0.55 & 0.22 & $\begin{array}{l}\text { Pérez-Fernández } \\
\text { et al. (2003) }\end{array}$ \\
\hline $\begin{array}{l}\text { Lavandula stoechas } \\
\text { ssp. pedunculata }\end{array}$ & 1.8 & 1.1 & 0.8 & 0.9 & Sánchez (2002) \\
\hline
\end{tabular}




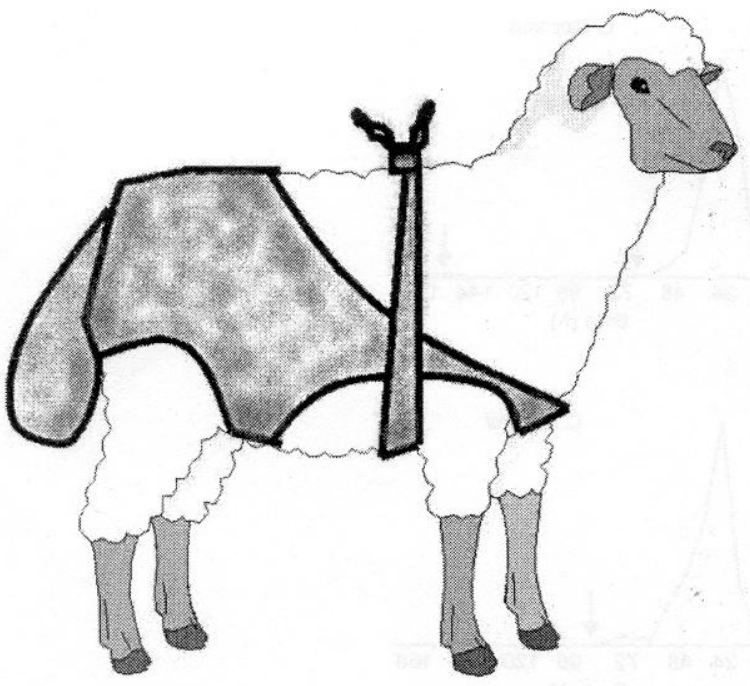

Figure 1. Schematic diagram of the faeces collection bag and its attachment to the ewe.

of vermiculite and subjected to greenhouse germination for 3 months, to check for any remaining germinable seeds. No germination was detected.

The total number of seeds defecated by each ewe was estimated from the seed density values (seeds of each species/g) in each sample, multiplied by the dry weight of the total faeces collected. The restless nature of the animals caused the loss of some attached bags during the experimental period, and seed densities had to be estimated for the lost samples. The seed defecation data (retrieved seeds) available for each animal, and the temporal patterns of seed defecation shown by the rest of the individuals, were used to make a conservative inference of the amount 'of lost seeds $(13.4 \%$ of retrieved seeds). The resulting numbers (retrieved, plus presumably lost seeds) are, hereafter, described as 'extrapolated seeds', and the results are presented both in terms of retrieved and extrapolated seeds.

A sample of 100 seeds from each species $(50$ in the case of $R$. sphaerocarpa) extracted from dung and a parallel set of control samples were subjected to a germination test in a growth chamber. Conditions $\left(12 \mathrm{~h}\right.$ light, 'day' temperature $22.5^{\circ} \mathrm{C}$ and 'night' temperature $11^{\circ} \mathrm{C}$ ) were similar to outdoor conditions in the area at the beginning of autumn. Seed germination was checked visually three times a week during a $75-\mathrm{d}$ germination trial period. Due to the lack of germination amongst retrieved Lavandula stoechas seeds, samples were subjected to a final treatment with gibberellic acid $(0.1 \%)$ and monitored for germination over an additional 14-d period. Gibberellic acid has been shown to be an effective stimulator of Lavandula angustifolia germination (Chavagnat, 1978).

Differences in germinability between experimental and control seeds were statistically evaluated by $\chi^{2}$ analyses. Due to the lack of normality in the data set, even after transformation, Mann-Whitney U-tests were used to test for differences in germination speed, measured as number of days taken for each seed to germinate since the beginning of the experiment. STATISTICA 5.0 for Windows (1998 Edition, StatSoft Inc., Tulsa, Oklahoma, USA) was used in all statistical analyses.

\section{Results}

A total of 1439 seeds was retrieved from the analysed dung samples, and the estimation of surviving seeds in 20-g samples (if none had been lost) extracted from dung raised this value to 1619 seeds (Table 2). The estimated percentage of defecated seeds varied between species, ranging from 10 to $23 \%$. Seeds of intermediate sizes $(H$. umbellatum, $L$. stoechas and Cytisus scoparius) were retrieved in comparatively larger numbers $(16-23 \%)$ than those of the smallseeded C. ladanifer $(10 \%)$ and the large-seeded R. sphaerocarpa $(12 \%)$.

Seeds were defecated clustered in time, with a clear peak between 24 and $40 \mathrm{~h}$ after feeding in all plant species (Fig. 2). In this time period, $73 \%$ of $R$. sphaerocarpa seeds, $65 \%$ of C. scoparius, $73 \%$ of H. umbellatum, $81 \%$ of $L$. stoechas and $76 \%$ of C. ladanifer seeds were defecated. No seeds were retrieved from dung defecated in the first $8 \mathrm{~h}$, but seeds were still detected $(1.42 \%) 76 \mathrm{~h}$ after feeding. C. scoparius seeds were found up to $160 \mathrm{~h}$ after feeding.

Table 2. Main results by species of seed retrieval from dung subsamples and estimations of the number and percentage (in brackets) of seeds defecated by the five ewes together. Extrapolated data include the amount of seeds presumably lost in samples that could not be analysed (see text for details)

\begin{tabular}{lccccc}
\hline & R. sphaerocarpa & C. scoparius & H. umbellatum & C. ladanifer & L. stoechas \\
\hline Retrieved seeds & 98 & 305 & 417 & 369 & 250 \\
Extrapolated seeds & 98 & 316 & 436 & 482 & 287 \\
Defecated seeds & $454(12.1 \%)$ & $1615(16.2 \%)$ & $2186(21.9 \%)$ & $1933(7.7 \%)$ & $1365(13.7 \%)$ \\
Extrapolated defecated seeds & $454(12.1 \%)$ & $1683(16.8 \%)$ & $2302(23.0 \%)$ & $2599(10.4 \%)$ & $1586(15.9 \%)$ \\
\hline
\end{tabular}



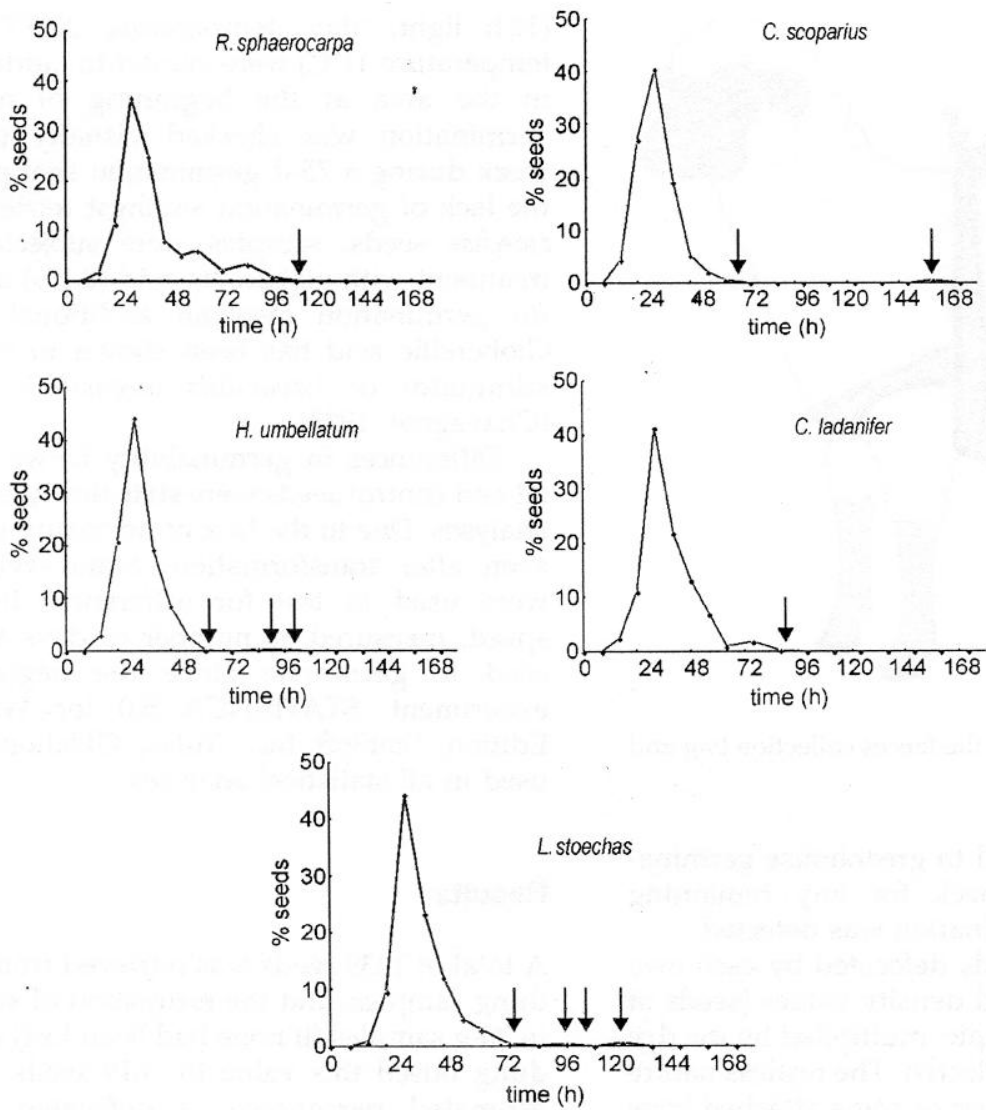

Figure 2. Temporal pattern of seed defecation after experimental seed feeding to sheep. Arrows point to the presence of seeds in dung samples with close-to-zero seed densities.

In the seed germination trial, all species but L. stoechas were germinable to some extent after passage through the sheep gut (Table 3). Germination was significantly improved in $H$. umbellatum $\left(\chi^{2}\right.$ test, $P<0.05)$ and marginally $(P<0.1)$ in $C$. scoparius. In $R$. sphaerocarpa and $C$. ladanifer no significant trend was found. No $L$. stoechas seeds retrieved from dung germinated, although $63 \%$ of control seeds did germinate $(P<0.001)$. The final treatment with gibberellic acid was followed by some germination in all species, except $C$. ladanifer and $L$. stoechas, but results remained essentially unchanged.

No significant effect on germination speed was observed in any of the species studied (Fig. 3). The acceleration observed in $C$. scoparius by gut

Table 3. Number of seeds germinated after $75 \mathrm{~d}$ in the growth chamber $\left[22.5^{\circ} \mathrm{C}\right.$ day $(12 \mathrm{~h}) / 11^{\circ} \mathrm{C}$ night] from control seeds and those extracted from sheep dung. $P$ values are for the $\chi^{2}$ test, except for $C$. ladanifer, where the Fisher exact test was used. Sample size for each species and treatment is $n=100$, except for $R$. sphaerocarpa $(n=50)$. Total germinated seeds after an additional $14-\mathrm{d}$ treatment with $0.1 \%$ gibberellic acid (GA) are also presented ( $89 \mathrm{~d}$ in total)

\begin{tabular}{lcccccc}
\hline Species & Dung & Control & $\chi^{2}$ value & $P$ value & Dung-GA & Control-GA \\
\hline R. sphaerocarpa & 36 & 34 & 0.19 & 0.663 & 39 & 34 \\
C. scoparius & 50 & 37 & 3.44 & 0.064 & 53 & 40 \\
H. umbellatum & 13 & 5 & 3.91 & 0.048 & 15 & 8 \\
C. ladanifer & 6 & 2 & - & $0.279+$ & 6 & 2 \\
L. stoechas & 0 & 63 & 91.97 & 0.000 & 0 & 63 \\
\hline
\end{tabular}

${ }^{+}$Fisher exact test, two-tailed. 

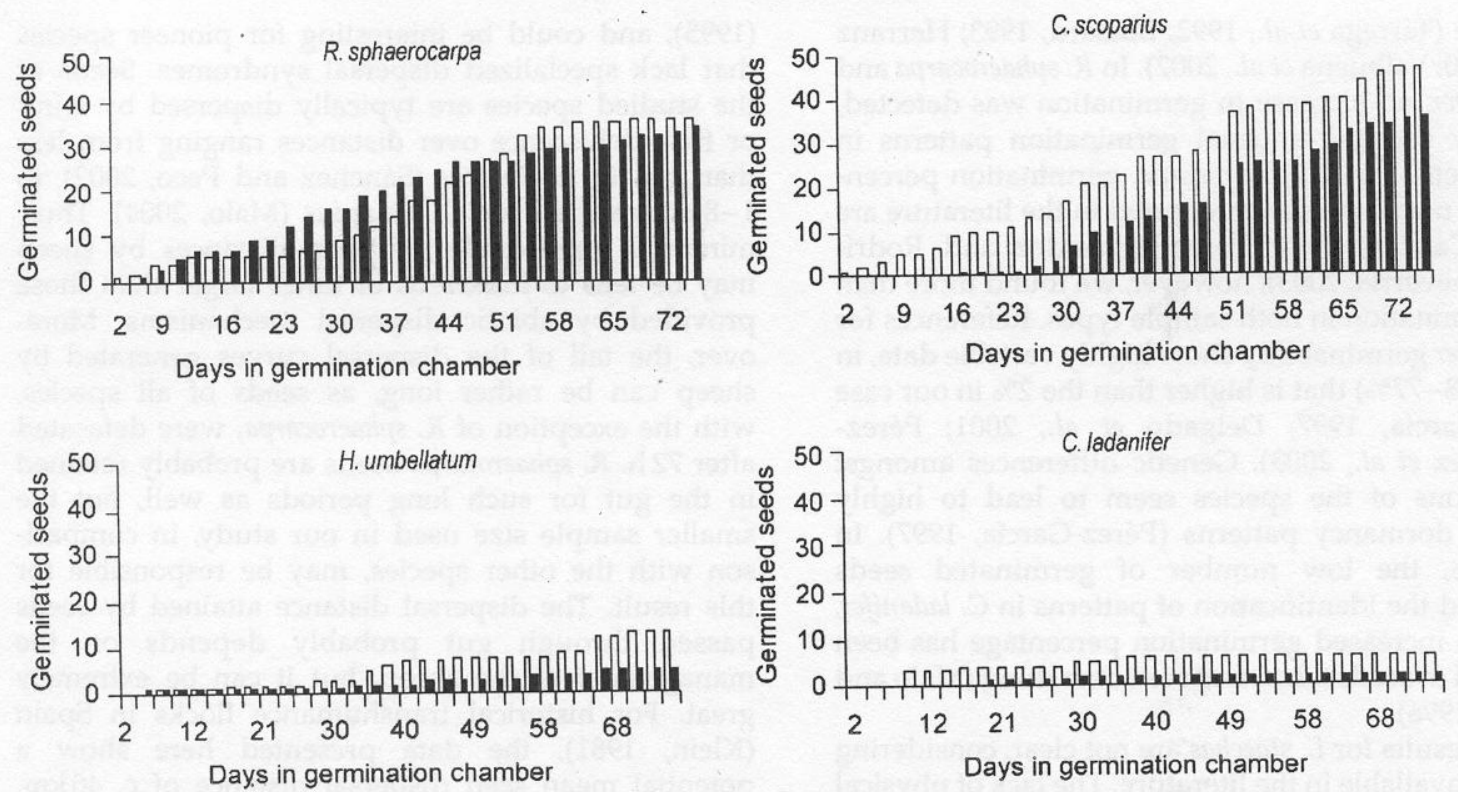

Figure 3. Cumulative temporal pattern of germination of defecated and control seeds in a growth chamber $\left[22.5^{\circ} \mathrm{C}\right.$ day (12 h) $/ 11^{\circ} \mathrm{C}$ night]. Light bars, defecated seeds; dark bars, control seeds.

passage was marginally significant (median elapsed time until germination 40 versus $49 \mathrm{~d}$, Mann-Whitney $\mathrm{U}=653.5, P=0.077)$. No clear trend was observed in $R$. sphaerocarpa (42 versus $33 \mathrm{~d}$; $\mathrm{U}=490.5, P=0.153$ ), $H$. umbellatum ( 40 versus $42 \mathrm{~d} ; \mathrm{U}=28.5, P=0.693$ ) or C. ladanifer (12.5 versus $24.5 \mathrm{~d} ; \mathrm{U}=0.0, P=1.000)$. The median time taken by control $L$. stoechas seeds to germinate was $19 \mathrm{~d}$.

\section{Discussion}

Seeds from several Mediterranean shrub species survived ingestion and gut passage by sheep, and could potentially be dispersed by free-ranging livestock. The observed gut passage times and survival percentages allow for 'long-distance seed dispersal. This dispersal capacity could help pioneer species to colonize distant locations.

The effects of seed size and hard-seededness are not clearly reflected in the final recovery of seeds. The low number of species used precludes the possibility of having any definite conclusion. A substantial portion of all five species of seeds passed through the gut with no apparent external damage. Contrary to expectations (Gardener et al., 1993), no trend towards a higher recovery of hard-coated seeds was observed in comparison with the soft-coated L. stoechas. A slight tendency towards medium size as optimal for survival could be inferred from our data, but any conclusion with such a low species number would be hazardous.
The species with the smallest seeds, C. ladanifer, showed the lowest retrieval, which suggests that such high losses could be attributed to digestion, rather than mastication. The higher surface-to-mass ratio of small seeds limits their coat thickness, leading to a stronger effect of digestive fluids, which could explain the difference in retrieval (10\% versus $23 \%$ ) compared to the Cistaceae species with middle-sized seeds (H. umbellatum). In contrast, the large-seeded R. sphaerocarpa showed a lower recovery percentage than its Leguminosae counterpart (C. scoparius). Mastication seems to be important for R. sphaerocarpa, as it was directly observed during the feeding experiment, and fragments of broken seeds were often found in dung samples. Data in the literature are contradictory on this point, as some studies (Staniforth and Cavers, 1977; Russi et al., 1992; Pakeman et al., 2002) have found a negative relationship between size and recovery, while Castro and Robles (2003) retrieved higher percentages of larger-sized seeds. These authors also found higher percentages of seed recovery (mostly between 35 and $45 \%$ ) among Cistaceae species than our tests (Castro and Robles, 2003).

Digestion may have a comparable effect to seed scarification of hard-seeded species, although our data only partially support the idea. Growth chamber data indicate an increase in germination percentages for $H$. umbellatum and a clear trend towards germination enhancement in C. scoparius. In both species, germination of control seeds was similar to that found in the 
literature (Tárrega et al., 1992; Bossard, 1993; Herranz et al., 2000; Valbuena et al., 2002). In R. sphaerocarpa and C. ladanifer, no increase in germination was detected, and they showed unusual germination patterns in control sets. For R. sphaerocarpa, germination percentages for untreated seeds reported in the literature are 4-5\% (Catalán, 1991; Pérez-Fernández and Rodríguez-Echeverría, 2003); however, we found more than $70 \%$ germination in both sample types. References for C. ladanifer germinability show highly variable data, in a range $(8-77 \%)$ that is higher than the $2 \%$ in our case (Pérez-García, 1997; Delgado et al., 2001; PérezFernández et al., 2003). Genetic differences amongst populations of the species seem to lead to highly variable dormancy patterns (Pérez-García, 1997). In our case, the low number of germinated seeds precluded the identification of patterns in C. ladanifer, while an increased germination percentage has been observed in seeds taken from red deer dung (Malo and Suárez, 1996).

The results for $L$. stoechas are not clear, considering the data available in the literature. The lack of physical dormancy in Labiatae could be blamed for the death of all seeds fed to the animals (Gardener et al., 1993; Baskin and Baskin, 2001). Thus, retrieved seeds with a good external appearance might have damaged embryos, as shown by the absence of response to gibberellic acid. However, it is known that L. stoechas seeds do germinate from sheep dung collected in shrublands of central Spain (Sánchez and Peco, 2002). In fact, subsequent re-assessment of collected material (Manzano and Sánchez, unpublished data) show that the germination percentage of $L$. stoechas seeds present in sheep dung in the previous experiment was close to $20 \%$. Therefore, the question of survival of soft-seeded species, such as $L$. stoechas, to gut passage remains open, although variability in germination of the species among populations could be also responsible for contradictory results (Chavagnat, 1978; Maher et al., 2000; Pérez-García et al., 2003).

No effect of ingestion was observed on the germination speed of retrieved seeds, but implications of changes in this feature would be difficult to interpret in terms of plant fitness. The acceleration of germination has advantages as well as disadvantages for seeds, and the net effect is completely species- and site-specific (Traveset and Verdú, 2002). Therefore, an absence of neat evolutionary pressure in any direction, and the fact that we really do not fully understand the detailed evolutionary scenario faced by seeds, precludes any further consideration of the subject (Janzen, 1983).

The temporal distribution of seed defecation facilitates increased dispersal distances for all seeds, and extremely long distances for the final tail. Clustered seed defecation patterns, with a long final tail, have been observed for sheep by Wallander et al.
(1995), and could be interesting for pioneer species that lack specialized dispersal syndromes. Seeds of the studied species are typically dispersed by wind or fruit dehiscence over distances ranging from less than $1 \mathrm{~m}$ in L. stoechas (Sánchez and Peco, 2002), to $1-8 \mathrm{~m}$ recorded for C. scoparius (Malo, 2004). Thus, minimum predictable dispersal distances by sheep may be tens to hundreds of times larger than those provided by abiotic dispersal mechanisms. Moreover, the tail of the dispersal curves generated by sheep can be rather long, as seeds of all species, with the exception of $R$. sphaerocarpa, were defecated after $72 \mathrm{~h}$. R. sphaerocarpa seeds are probably retained in the gut for such long periods as well, but the smaller sample size used in our study, in comparison with the other species, may be responsible for this result. The dispersal distance attained by seeds passed through gut probably depends on the management of the sheep, but it can be extremely great. For historical transhumance flocks in Spain (Klein, 1981), the data presented here show a potential mean seed dispersal distance of c. $40 \mathrm{~km}$, as sheep moved about $25-30 \mathrm{~km}$ a day, and the dispersal peak found in our study was around $32 \mathrm{~h}$ (Fig. 2). The $1.4 \%$ of the seeds that we retrieved after $76 \mathrm{~h}$ suggests potential long-distance dispersal exceeding at least $80 \mathrm{~km}$. Although autumn transhumance takes place when most dry-fruited shrubs have passed their fruiting peak, some shrubs retain part of their seed crop on the plant (e.g. $R$. sphaerocarpa, L. stoechas), thus being available for moving livestock. Although the cost of gut passage for dry-fruited species is undoubtedly high (Traveset and Verdú, 2002), ingestion can be advantageous for plant establishment, due to the potential benefits of long-distance dispersal. In fact, colonization at landscape scales, and geographical-scale changes in vegetation, such as the Holocene migration of plants, can only be understood in terms of dispersal distances such as those potentially provided by migrant herbivores, such as reindeer (Rivals et al., 2004), or other rare events (Bullock and Clarke, 2000; Cain et al., 2000).

The transit time of seeds in herbivore guts and their survival in non-anecdotal numbers highlight the potential role played by endozoochory for dry-fruited shrub species in the Mediterranean area (Pakeman, 2001). Extensive grazing of shrublands by freeranging herds is a common practice in the area, and seeds of several species have been found in herbivore dung. Although the role of herbivory in shrub colonization and maintenance is far from well understood, and negative effects of grazing on seedlings are common (Bellingham and Coomes, 2003), gut passage provides dry-fruited species with extensive seed shadows, and this may allow for the rapid spread of their populations. 


\section{Acknowledgements}

The authors would like to thank Jaime Thos at the Veterinary Faculty of the UCM and all the people who helped in the field and laboratory work. A.M. Moigne provided valuable references, and comments from two anonymous referees improved the manuscript. This study was funded by the Spanish Ministry of Science and Technology (CICyT projects AMB 99-0382 and REN 2003-01562). P. Manzano has a postgraduate grant from the Spanish Ministry of Education, Culture and Sports.

\section{References}

Azcárate, F.M. (2003) Hormigas granívoras en pastizales y matorrales mediterráneos: interacciones y efectos sobre la vegetación. PhD thesis, Universidad Autónoma de Madrid.

Baskin, C.C. and Baskin, J.M. (2001) Seeds. Ecology, biogeography, and evolution of dormancy and germination San Diego, Academic Press.

Bellingham, P.J. and Coomes, D.A. (2003) Grazing and community structure as determinants of invasion success by Scotch broom in a New Zealand montane shrubland. Diversity and Distributions 9, 19-28.

Bossard, C.C. (1993) Seed germination in the exotic shrub Cytisus scoparius (Scotch broom) in California. Madroño 40, 47-61.

Bullock, J.M. and Clarke, R.T. (2000) Long distance dispersal by wind: measuring and modelling the tail of the curve. Oecologia 124, 506-521.

Cain, M.L., Damman, H. and Muir, A. (1998) Seed dispersal and the Holocene migration of woodland herbs. Ecological Monographs 68, 325-347.

Cain, M.L., Milligan, B.G. and Strand, A.E. (2000) Longdistance seed dispersal in plant populations. American Journal of Botany 87, 1217-1227.

Campbell, J.E. and Gibson, D.J. (2001) The effect of seeds of exotic species transported via horse dung on vegetation along trail corridors. Plant Ecology 157, 23-35.

Castro, J. and Robles, A.B. (2003) Dispersión endozoócora por ganado ovino de las semillas de seis especies de cistáceas. pp. 645-650 in Robles, A.B.; Ramos, M.E.; Morales, M.C.; de Simón, E.; González-Rebollar, J.L.; Boza, J. (Eds) Pastos, desarrollo y conservación. Sevilla, Spain, Junta de Andalucía.

Catalán, G. (1991) Semillas de árboles y arbustos forestales Madrid, Spain, ICONA.

Chavagnat, A. (1978) Étude de la germination des semences de Lavandula angustifolia au laboratoire. Seed Science and Technology 6, 775-784.

Delgado, J.A., Serrano, J.M., López, F. and Acosta, F.J. (2001) Heat shock, mass-dependent germination, and seed yield as related components of fitness in Cistus ladanifer. Environmental and Experimental Botany 46, 11-20.

DeSimone, S.A. and Zedler, P.H. (2001) Do shrub colonizers of Southern Californian grassland fit generalities for other woody colonizers? Ecological Applications 11, 1101-1111.

Gardener, C.J., McIvor, J.G. and Jansen, A. (1993) Survival of seeds of tropical grassland species subjected to bovine digestion. Journal of Applied Ecology 30, 75-85.

Herranz, J.M., Ferrandis, P. and Martínez-Sánchez, J.J. (2000) Influence of heat on seed germination of nine woody Cistaceae species. International Journal of Wildland Fire 9, 173-182.

Janzen, D.H. (1983) The dispersal of seeds by vertebrate guts. pp. 232-262 in Futuyma, D.J.; Slatkin, M. (Eds) Coevolution. Sunderland, Massachussets, USA, Sinauer Associates.

Janzen, D.H. (1984) Dispersal of small seeds by big herbivores: foliage is the fruit. American Naturalist 123, $338-353$.

Keeley, J.E. (1991) Seed gemination and life history syndromes in the California chaparral. Botanical Review 57, $81-116$.

Klein, J. (1981) La Mesta (2nd edition). Madrid, Spain, Alianza Editorial.

Maher, J., Gerasopoulos, D. and Maloupa, E. (2000) Temperature and light effects on germination of Lavandula stoechas seeds. Acta Horticulturae 541, 261-264.

Malo, J.E. (2004) Potential ballistic dispersal of Cytisus scoparius (Fabaceae) seeds. Australian Journal of Botany 52, 653-658.

Malo, J.E. and Suárez, F. (1996) Cistus ladanifer recruitment Not only fire, but also deer. Acta Oecologica 17, 55-60.

Pakeman, R.J. (2001) Plant migration rates and seed dispersal mechanisms. Journal of Biogeography 28, 795-800.

Pakeman, R.J., Digneffe, G. and Small, J.L. (2002) Ecological correlates of endozoochory by herbivores. Functional Ecology 16, 296-304.

Pérez-Fernández, M.A. and Rodríguez-Echeverría, S. (2003) Effect of smoke, charred wood, and nitrogenous compounds on seed germination of ten species from woodland in Central-Western Spain. Journal of Chemical Ecology 29, 237-251.

Pérez-Fernández, M.A., Rodríguez-Echeverría, S., CalvoMagro, E. and David-Antonio, C. (2003) Germination of selected perennial plant species from western Spain under nitrogen, light and wet and dry heat treatments. Journal of Mediterranean Ecology 4, 23-33.

Pérez-García, F. (1997) Germination of Cistus ladanifer seeds in relation to parent material. Plant Ecology 133, 57-62.

Pérez-García, F., Hornero, J. and González-Benito, M.E. (2003) Interpopulation variation in seed germination of five Mediterranean Labiatae shrubby species. Israel Journal of Plant Sciences 51, 117-124.

Rivals, F., Kacimi, S. and Moutoussamy, J. (2004) Artiodactyls, favourite game of prehistoric hunters at the Caune de l'Arago Cave (Tautavel, France). Opportunistic or selective hunting strategies? European Journal of Wildlife Research 50, 25-32.

Russi, L., Cocks, P.S. and Roberts, E.H. (1992) The fate of legume seeds eaten by sheep from a Mediterranean grassland. Journal of Applied Ecology 29, 772-778.

Sánchez, A.M. (2002) Colonización y regeneración de Lavandula stoechas subsp. pedunculata en un paisaje 
agrario abandonado de la Sierra de Guadarrama. PhD Thesis, Universidad Autónoma de Madrid.

Sánchez, A.M. and Peco, B. (2002) Dispersal mechanisms in Lavandula stoechas subsp. pedunculata: autochory and endozoochory by sheep. Seed Science Research 12, 101-111.

Staniforth, R.J. and Cavers, P.B. (1977) The importance of cottontail rabbits in the dispersal of Polygonum spp. Journal of Applied Ecology 14, 261-268.

Tárrega, R., Calvo, L. and Trabaud, L. (1992) Effect of hightemperatures on seed-germination of two woody Leguminosae. Vegetatio 102, 139-147.

Thanos, C.A., Georghiou, K., Kadis, C. and Pantazi, C. (1992) Cistaceae: a plant family with hard seeds. Israel Journal of Botany 41, 251-263.

Traveset, A. and Verdú, M. (2002) A meta-analysis of the effect of gut treatment on seed germination. pp. 339-350 in Levey, D.J.; Silva, W.R.; Galetti, M. (Eds) Seed dispersal and frugivory: Ecology, evolution and conservation. Wallingford, CABI Publishing.

Valbuena, L., Luis-Calabuig, E. and Tárrega, R. (2002) Relationship between thermal shock and germination in five Mediterranean shrubs. pp. 93-98 in Trabaud, L.; Prodon, R. (Eds). Fire and biological processes. Leiden, The Netherlands, Backhuys.

Wallander, R.T., Olson, B.E. and Lacey, J.R. (1995) Spotted knapweed seed viability after passing through sheep and mule deer. Journal of Range Management 48, 145-149.

Received 7 July 2004

accepted after revision 26 October 2004

(c) $\mathrm{CAB}$ International 2005 